\title{
College students internship education research based on sports club model
}

\author{
Zhao Xing \\ (Hubei Polytechnic lnstitute Xiaogan Hubei 432000)
}

\begin{abstract}
In recent years, physical education reform is constantly carrying out in our country, and sports related student-recruitment number has increased almost five times in 10 years. Traditional sports major internship teaching mode can't meet the needs of the society for sports talents, besides, sports internship education goal also gradually breaks away from social needs. In view of the problems in current sports major students' internship education like imperfect education management, lack of internship base construction, internship education being a mere formality, and the gap between graduates qualities, skills and social posts skill requirements, this paper puts forward a kind of sports club internship education model. Innovative sports major graduates' internship education model is to enhance students' practical ability to work as the goal, establish and manage sports clubs by interns guided by school management department. These clubs insist on independent operation and management, provide diversified and hierarchical internship teaching, provide interns internship posts in sports cause management and sports consulting management, which not only plays a positive role in promoting students sports skills and overall quality, but improves the independence of students' active participation in internship education, strengthens students' operating knowledge of sports related enterprises and institutions, and broadens the employment channels of interns.
\end{abstract}

Keywords- Physical education; Internship education; Sports club model

\section{INTRODUCTION}

In 1999, our country adopted the reform of enrollment expansion of colleges and universities to solve the problem of economic and employment problems. Hubei province actively promoted the policy of higher education popularization. The recruitment number of students in sports related major in the province's colleges and universities turned five times in a decade. From 2000 to 2012, Hubei province sports related recruitment situation is shown in Figure 1.

Surge in enrollment caused the concerns education experts held for physical education's teaching quality. From graduate employment situation and labor market feedback, it can be seen that confined to the lack of qualified teachers, and teaching reform lagging behind extended enrollment rate, sports major students' knowledge and skills gained from basic education and internship education stage can't meet the demand of social position. The internship education which aims to guide students to apply the theory and knowledge that they have learned to practice lacks content and has outdated form, which results in that many sports major students can't understand the actual work content and lacks basic skills qualified for jobs. With the sharp increase of university sports related major graduates year by year, problems of structural differences in sports major talents demand appears in the labor market. From the latest five years of sports related major graduates' employment situation, it can be seen that the current college sports major internship education situation has big issues, so the research of sports major internship education models and curriculum setting have already become the focus in sports education.

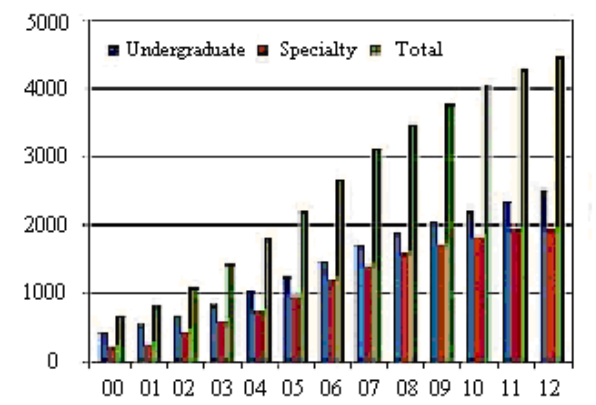

Figure 1. 2000-2012 Hubei province sports related specialized student enrollment

\section{THE CURRENT SITUATION OF SPORTS SPECIALIZED COLLEGE STUDENTS’ INTERNSHIP EDUCATION}

Internship education can help interns learn to apply basic sports theory and sports knowledge to real work process and master the basic skills to meet social position requirements. Currently, the society mainly needs sports professionals such as sports consulting professionals, sports business operation and management talents and professional sports coaches, therefore, the main goal of our country's sports education internship should be to cultivate and exercise work ability and sports skills of the interns. According to the existing research findings of the sports related major internship education modes in universities, the sports major college students' internship education in China is found to have three categories:

The first type is real post internship education mode. That is mainly to arrange students to work in enterprises and institutions after basic course and specialized course learning. Currently, enterprises and institutions which can provide work opportunities for sports related major are mainly sports related government departments, sports clubs and sports supplies production and sales company, etc. In real post internship education phase, job rotation is adopted to make students understand enterprise management and operation pattern. By actual participation in enterprise management, 
marketing, and sports guidance work, the students can grasp actual operation ability and related skills needed for future jobs. Real work internship education mode can improve students' adaptability, improve the employment competitiveness of graduates, thus it has been accepted by the majority of colleges and universities and is taken as a valid sports talents education mode.

The second type is paid internship education mode. Paid internship refers that interns accept a certain salary as a reward for the enterprise normal work in internship stage. The premise of paid internship education model is that students need to be involved in related training organized by school or enterprise before internship. The students who have passed knowledge and skills assessment after training can get paid internship opportunities. Universities providing paid internship education usually offer some training opportunities or jobs for students at the same time of basic course teaching. Enterprises providing internship opportunities also participate in curriculum development and part of the curriculum teachers are personnel in the enterprise. Paid internship education mode is the mode most likely to fulfill the purpose of the internship education, but currently the internship education mode is popular with the higher vocational education teaching, but it is relatively scarce in higher education.

The third mode is base internship education mode. Internship bases are mainly set by joint cooperation of school and enterprise. Enterprises provide long-term internship opportunities for students, and are more actively involved in internship management. Different from real work internship education mode, internship education base usually has joint organization and management by specialists or professional departments which implements the regularization and organization of internship management. This internship education model is relatively common in colleges and universities with more affiliated enterprises. Internship bases provide enterprises with research and development or experimental service. These bases are equipped with perfect equipments, student can participate in enterprise's research, development and application development work during internship, therefore base internship education mode is the most effective mode to cultivate high quality technology talents.

In recent years, the development of paid internship education and base internship education modes is relatively obvious, which improves the enthusiasm of students to participate in internship and its effect is remarkable, but sports related major internship education in China still needs further perfecting.

\section{PROBLEMS OF INTERNSHIP EDUCATION FOR SPORTS MAJOR COLLEGE STUDENTS}

Along with the rapid development of social economy in our country, our people's demand of social and cultural life is higher and higher. The society needs a lot of sports talents to promote the development of sports undertakings, but past internship education mode already can't adapt to the social demand for sports talents. In 2012, a survey result of 300 sports or related major graduates from universities and colleges in Hubei province reveals that graduates' satisfaction for internship education is low. The internship education survey results are shown in Table I:

TABLE I. A SURVEY ON GRADUATES’ SATISFACTION FOR INTERNSHIP EDUCATION

\begin{tabular}{|l|c|}
\hline \multicolumn{1}{|c|}{ survey projects } & Satisfaction \\
\hline $\begin{array}{l}\text { Schools' internship education } \\
\text { management mode }\end{array}$ & 3.48 \\
\hline internship posts & 2.98 \\
\hline & 2.96 \\
\hline Internship experience & 3.22 \\
\hline Internship content & 2.12 \\
\hline Internship tutor & 3.16 \\
\hline internship management & 3.44 \\
\hline
\end{tabular}

Satisfaction survey takes five-point scale. That is 5 points for very satisfied and 1 point for very dissatisfied. From table 1, it can be seen that the current internship education model is hard to get students satisfaction since current students' internship education satisfaction level is generally not high. It can be found according to the results of interviews that the current internship units which can provide sports related internship are less in Hubei province scope. Internship posts are most sales, and some universities organize unified internship education. But some schools' internship education management is loose, which leads to very little work experience gained in internship education stage, so graduates have low satisfaction degree of internship education. Internship education is difficult to shorten the differences between students' quality skills and social posts skill requirements. The current internship education pattern mainly has the following three questions:

First of all, the internship education management for sports major students is not perfect. With the enlargement of school running scale and enrollment increase, the proportion of sports professional teachers is decreased. Therefore, professional sports teachers' number at present stage is unable to meet the demand of basic internship teaching, and there are few specially assigned teachers for the management work of most internship for students majoring in physical education. According to the survey of Hubei province sports students' recruitment enterprises, most college sports major students' internship management work is usually responsible for grade counselors due to the teacher positions or limited education funds. There is no specific counselor or professional employment guidance teacher who is responsible for it, which causes loose students internship education management, and it is hard to improve institutionalization and organization internship of management in all colleges and universities. 
Second, the construction of internship base is still insufficient. Due to the limited education funds, only large state-owned enterprises or foreign enterprises have the strength and ability to cooperate with schools to establish internship base, so internship base construction and operating difficulties still are the biggest dilemma facing the base internship education mode. The shortage of internship venues and equipment and the imperfect teaching material cause interns' less satisfaction for most base internship teaching effect, which limits the interns innovation abilities, and it is difficult to enrich interns' social experience.

Finally, part internship education in colleges and universities in economically underdeveloped areas becomes a mere formality without internship content development. Due to lack of good internship enterprises, some college students spend more energy on a variety of grade examination or professional certificate examination, and lack internship enthusiasm. They even think the impact of internship education on career planning and employment is not big, and ignores the advantage of improving actual operation ability in the process of internship education. Internship education is seen as one of the important practical courses of higher education. If the school's internship management on students is loose with no unified internship management arrangement and corresponding evaluation, and also allows autonomous students internship, students may not participate in the internship and finish school internship evaluation by submitting a relevant internship enterprise certificate, which leads to a mere formality of students internship.

In view of the problems of current sports major students internship education such as imperfect management, lack of internship base construction, being a mere formality, the difference between graduate qualities, skills and social job skill requirements, this paper proposes a sports club internship education mode to improve current internship education in colleges and universities in our country.

\section{THE SPECIFIC CONTENT AND FEATURES OF SPORTS} CLUB MODE

\section{A. Sports club internship education model}

Sports club internship education mode mainly takes freedom of choice, independent management as the basic principles, which completes the club establishment of predominantly single sport by college interns under the guidance of professional sports tutors and relevant tutors. Interns can choose their favorite club to participate in the autonomous management and complete hierarchical internship teaching.

Sports clubs set can be single sports clubs of football, basketball, volleyball, sprint, table tennis, badminton, and tai chi, etc. The size of the club is decided by students themselves, but shall not be less than a certain number to ensure the normal operation of the club. The established clubs shall have complete management department to simulate the professional club management operations. Because the established internship clubs are non-profit organizations, the club's financial management problems are not considered, but schools shall provide each club a certain place and a small amount of operating funds for the daily management work.

The important work in sports club setting is to set management system and election management staff. Regulations of clubs may refer to formal professional clubs, and may not be easily modified as soon as confirmed. The management duties and functions of elected club corresponding department management and grass-roots directors should be confirmed by professional mentors. Internship clubs don't have to be established each year, and take professional club management mode. Each year, certify the club members, and then select management directors and secretaries, and directors and secretaries elected may take the working experience as an internship education, or create other internships. But club management department is responsible for the internship posts by contacting with the outside world. Internship can be extended to the guidance of community sports instructions and fitness coach jobs, and is no longer limited to the original internship posts in sports products companies to make sure every intern has the opportunity to take part in the internship. Clubs are responsible for the interns' internship salary negotiation with enterprises and institutions and accident insurance during the internship to ensure the smooth internship education. At the end of the internship, organize the interns to hand in internship report in the club in order to evaluate the internship education results.

\section{B. The characteristics of sports club internship education mode}

Sports club internship education mode can help interns actively participate in the sports work, in which the interns' personal interest is given priority to. It offers interns all aspects of job opportunities including sports management, sports exercise guidance, marketing and human resources management and so on. Internship content is richer. It fully embodies the student-centered internship teaching management idea.

In addition, club internship education model needs only one setting up and after the club run on track, the role of employment guidance teacher is changed from organizers to supervisors and assistants, which greatly reduces the employment guidance teachers' work pressure. Schools with no professional internship education teachers, sports club internship education model can largely alleviate the pressure of teacher shortage.

Club internship mode can provide students with a variety of different jobs. Students can freely choose to go to community sports service station of public welfare or a paid internship in Sports Company. This changes the limitations of previous school-arranged internship jobs, offers a variety of internship opportunities for graduates' career planning, 
and meets the diverse needs of the interns for internships with different properties.

\section{The impact of sports club model on college students' internship education}

By establishing sports internship teaching club of each single sport association, a sound club management operation mechanism is formed, which can really realize the internship education with the combination of theory and practice. Club internship mode's impact on improving college students' internship education is mainly manifested in two aspects:

First of all, the club mode changes the traditional internship teaching pattern, which innovatively put forward a internship mode with students' autonomous management and independent operation. This not only changes the past single internship education content and form, but can widen the channel of students internship. Students can go to communities, enterprises and institutions, have different work experience, greatly enrich students' internship, and in the end hugely impact the students career planning. Club internship education pattern breaks the space and time limit of internship education and will be the important achievement of internship education reform.

Second, club internship mode broadens the graduates' employment channels, increases the employment opportunities, which will continue to shorten the gap between graduates quality and skills and social skills required in order to change the current Labor market's structural differences. In recent years, in view of the escalating of the breaking away of current higher education in our country from the actual social demand, the internship education should be improved to change the present situation of the lack of practical work ability training in higher education, which can improve the working ability of college students and help graduates get into the social work as soon as possible.

Although sports club internship education mode can improve the existing internship education, the club internship education mode still needs further perfect theory study and practice research.

\section{CONCLUSION}

Sports club internship education mode is an innovative internship education mode on the basis of the existing education innovation. By sports teaching club, students' internship education can be expanded in time and space, and play a positive role in improving students' sports skills and the overall quality. It can improve students' initiative to participate in the internship education, enhance students' knowledge of enterprises and institutions operating relating sports, and enhance the consciousness of students' autonomous management. People-oriented internship education model will enhance harmonious body and mind development, and plays a special role in cultivating healthy personality.

\section{REFERENCES}

[1] Jianbo Bai, The current situations exist in career guidance in colleges and universities and countermeasures in the construction of the contingent. Education and Vocation. 2008.

[2] Bing Chang.Try to talk about the universities career instruction team of professional, professionalism, and experts construction. China University Students Career Guide. 2007.

[3] Franke, M.L., Carpenter, T., Fennema, E., Ansell, Behrend, J.Understanding teachers self-sustaining, generative change, in the context of professional development. Teaching and Teacher Education. 1998.

[4] Research on Professional Construction of the Grass-roots Managers in Universities and Colleges in Jiangxi Province [A]. Proceedings of 2011 International Conference on Management Science and Intelligent Control(ICMSIC 2011) VOL.01[C]. 2011.

[5] Current Situation and Development Trend of Construction of University Informatization [A]. Proceedings of the 2011 International Conference on Education Science and Management Engineering(part 2)[C]. 2011.

[6] Exploration on the Construction of Implementation System of College Students' Career Development Education[A]. Proceedings of the 2011 International Conference on Information , Services and Management Engineering(ISME 2011)(Volume 2)[C]. 2011.

[7] A Multi-agent Based Research about College Student's Self-service System of Career Planning[A]. Proceedings of 2010 The 3rd International Conference on Computational Intelligence and Industrial Application(Volume 4)[C]. 2010. 